\title{
N 87-11098
}

\author{
NICKEL-HYDROGEN LOW-EARTH-ORBIT \\ TEST PROGRAM
}

\author{
Joseph K. McDermott \\ Martin Marietta Denver Aerospace \\ Denver, Colorado
}

\section{ABSTRACT}

The incorporation of nickel-hydrogen technology for low-earth-orbit (LEO) spacecraft applications require the establishment of a data base. An extensive test program has been established to provide this data base. This paper outlines the test program and presents preliminary test results.

\section{INTRODUCTION}

The vast majority of spacecraft secondary energy storage systems flown in the last two decades were nickel-cadmium batteries. Such applications took advantage of the inherently long cycle life, a good specific energy and high reliability. The hermetically-sealed nickel-cadmium system required a sophisticated charge control system, however, and as a result of temperature sensitivity required operation under close environmental control. Increasing spacecraft power requirements dictated the need toward a higher performance battery system capable of a 10 year mission life with deeper depths-of-discharge (DOD's) and variable load profiles. In the past, the extensive data base for nickel-cadmium systems had restrained aerospace contractors from investigating alternative energy storage systems. However, the limitations of nickel-cadmium batteries, particularly usable energy density, have provided strong economic incentives for a new system, and led to the recent development in nickel-hydrogen cell technology.

Nickel-hydrogen cell and battery technology has matured to the point where a viable choice now exists for current and future aerospace energy storage applications. The nickel-hydrogen system offers a true hermetically sealed design capable of thousands of maintenance free cycles without need for complex charge control circuitry or close environmental control. The real potential of nickel-hydrogen systems has aroused aerospace contractors to conduct in-house studies and investigate the feasibility of nickel-hydrogen implementation. Nickel-hydrogen cell technology represents the best engineering choice for numerous power storage systems, and with the 
establishment and expansion in its data base, which is presently insufficient (ref. 1), the nickel-hydrogen system will become the practical choice.

Nickel-hydrogen battery cell technology has been successfully demonstrated for geosynchronous (GEO) orbit applications, both by ground testing and in-flight performance. The GEO data base cannot, however, be extrapolated to provide pertinent LEO data. Applications of nickel-hydrogen technology in LEO require the development of a cycle 1 ife data base with DOD's in the $40 \%$ to $60 \%$ range. A nickel-hydrogen test program was thus established to provide this LEO data base.

\section{TEST PLAN}

Table 1 identifies the suppliers and numbers of cells procured for nickel-hydrogen LEO testing. Eagle-Picher and General Electric were selected for the procurement of 36 Air Force designed nickel-hydrogen cells. Six (6) Yardney cells were also procured. Four cells from Eagle-Picher are identified on Table 1 as COMSAT designed cells. Eagle-Picher provided these cells to Martin Marietta for LEO testing. The general concensus by the aerospace industry is that the COMSAT cell is not adequately designed for LEO application. The addition of the four COMSAT cells to the test program will possibly provide evidence to either support or negate this assumption.

The matrix for the nickel-hydrogen testing is summarized in Table 2. The primary area of interest is $40 \%$ DOD. This would translate into appreciable weight savings when compared to nickel-cadmium systems (ref. 2). It is also assumed that $40 \%$ DOD is a conservative test parameter. The test temperature of $10^{\circ} \mathrm{C}$ is based on the present thermal design capabilities of typical spacecraft (ref. 3 ). Vendors predict that 20,000 cycles at $40 \%$ DOD and $10^{\circ} \mathrm{C}$ is attainable with their nickel-hydrogen cells. The $60 \%$ DOD test will serve two main purposes: first accelerate the testing and provide early failure rate data; and second, characterize cell performance at a higher DOD. The added temperature of $20^{\circ} \mathrm{C}$ is of interest because further weight and cost savings could be possible if the requirement for maintaining battery temperature was less stringent. All testing conducted under this matrix will be a 90 minute LEO regime consisting of a 55 minute charge and a 35 minute discharge. The 90 minute LEO is generic, and also accelerates testing to an extent. The charge control parameter was considered to be a significant factor with regard to LEO testing. Analysis of test equipment capabilites and the results of preliminary testing support charge control utilizing a current integrator. Charge control is therefore maintained by ending the charge and discharge phase after a predetermined capacity is achieved. A recharge fraction roughly between 1.05 and 1.10 (dependent upon test temperature and cell $\mathrm{life}$ ) will be maintained for all testing. 


\section{TEST PROCEDURE}

All the nickel-hydrogen cells subjected to Life Cycle Tests have aluminum collars. The collars provide cell support to the test fixture and aid in thermal management. All cells are tested in the horizontal position. Possible problems have been identified with testing in the vertical position, therefore the horizontal testing requirement was imposed. It is also the general concensus that testing the cells in the horizontal position will aid electrolyte distribution within the cell. The test fixture for mounting and thermal management consists of copper tubing pressure-fitted between two aluminum plates. Each test fixture has mounting provisions for four cells. The test fixtures are then mounted in an environmental test chamber. The test fixture temperature is controlled by a circulator bath. The chamber temperature is set to match the test fixture. Preliminary test data shown in Figure 1 indicates the delta temperature between cell case and test fixture is less than $5^{\circ} \mathrm{C}$ during LEO testing.

Nearly all the nickel-hydrogen cells tested have strain gages. The strain gages allow the cell pressure to be monitored during LEO testing. Possible charge control utilizing cell pressure data has been proposed for nickel-hydrogen cells, but for our test program the pressure data is for characterization purposes only. It has been shown that a direct relationship exists between the state-of-charge and the pressure of a nickel-hydrogen cell (ref. 4,5$)$.

Table 3 outlines the actual test parameters for nickel-hydrogen LEO testing. The discharge capacity for the $40 \%$ DOD testing is set at 20.0 ampere-hours. This translates into a discharge current of 34.4 amperes. The charge current for the $40 \%$ DOD testing is set between 22.9 amperes and 24 amperes. Depending upon cell test temperature and $1 \mathrm{ife}$, the recharge fraction is set between 1.05 and 1.10 by adjusting the charge current. The end of a discharge phase is when 20.0 ampere-hours has been removed. The end of a charge phase is when 21 to 22 ampere-hours (dependent upon test temperature and 1 ife) has been returned. The $60 \%$ DOD testing follows the same recharge fraction control scenario as the $40 \%$ DOD testing. The discharge current for $60 \%$ DOD testing is set at 51.5 amperes while the charge current is set between 34.3 amperes and 36.0 amperes.

For each test group, a representative cell will be temperature monitored to thermally characterize the cell and test fixture (equipment). The coolant plate will also contain thermocouple(s) to ensure test temperature is held as close to $10^{\circ} \mathrm{C}$ or $20^{\circ} \mathrm{C}$ as possible. Cell pressure will be monitored by strain gages. This data will be utilized for characterization purposes only and will be reported in the future. Due to safety concerns, all testing was conducted in an enclosed environmental chamber equipped with a nitrogen purge system. 
The definition of a cell failure during life cycle tests is the inability of a cell to support an end-of-discharge voltage of 1.0 volt. At the discretion of the test engineer, an attempt may be made to recondition the cell. Cells which cannot support a 1.0 volt end-of-discharge voltage will be removed from the test group. Life cycling will then continue on the remaining cells. Analysis of the data from a failed cell will determine final cell disposition.

A capacity test will be conducted every 1,000 cycles starting with cycle 0 . The capacity test will consist of a cell discharge to 1.0 volt, followed by a 16 hour charge at 5.0 amperes, followed by a 25.0 ampere discharge to 1.0 volt per cell. The objective of the capacity test is to characterize cell degradation in relationship to LEO cycling. The capacity check may also be in effect a reconditioning cycle, due to the fact the cell is fully recharged. The data from the capacity test may also indicate possible electrochemical changes within the cell associated with LEO cycling.

\section{TEST RESULTS}

Test results to date are primarily focused around the first delivery of 12 Air Force designed nickel-hydrogen cells and the four COMSAT cells. The Acceptance Test Procedure (ATP) conducted at the vendor on the twelve Air Force designed nickel-hydrogen cells during late May 1985 revealed a capacity range of 59.8 to 63.2 ampere-hours $\left(10^{\circ} \mathrm{C}\right.$ test, 34.4 ampere discharge to 1.0 volt per cell). Final ATP testing at the vendor was completed in June 1985. The cells were first tested in the Power Sources Laboratory in late July 1985. Initial capacity checks (five continuous cycles) consisting of a 5.0 ampere charge for 16 hours followed by a 25.0 ampere discharge to 1.0 volt per cell revealed a fourth cycle capacity range of 45.0 to 48.2

ampere-hours. Table 4 lists the capacities for both the vendor ATP data and the fourth cycle capacity check conducted in-house. The in-house capacity discharge was continued to an end-of-discharge voltage of 0.5 volt. significant residual capacity was noted in the cells as shown in Table 4. A typical capacity discharge cycle is depicted in Figure 2. A second, distinct voltage plateau can be seen at 0.7 volt. All twelve nickel-hydrogen celis shared this second plateau characteristic.

The first twelve vendor cells were divided into two groups. The first test group consisted of eight series-connected cells tested at $10^{\circ} \mathrm{C}$ and $60 \%$ DOD. The initial capacity $(25.0$ A to $1.0 \mathrm{~V} / \mathrm{cel} 1 \mathrm{l})$ of this cell/battery test group was 55.1 ampere-hours. Figure 3 depicts the end-of-discharge voltage and recharge fraction plots for this test to date. The remaining four cells were series-connected and placed on tests at $20^{\circ} \mathrm{C}$ and $60 \% \mathrm{DOD}$. The initial capacity of this cell/battery test group was 44.0 ampere-hours. Figure 4 depicts the end-of-discharge voltage and recharge fraction plots for this four cell test group to date. 
The four COMSAT cells were series-connected and placed on tests at $10^{\circ} \mathrm{C}$ and $40 \%$ DOD. The initial capacity of this four-cell test group was 62.5 ampere-hours. Figure 5 depicts the end-of-discharge voltage and recharge fraction plots for this four-cell test group to date.

Testing has not been initiated to date on the 24 recently received vendor cells nor the 6 Yardney cells. LEO testing on these cells will be underway by December 1985. The addition of 36 more cells to the test program in 1986 will be the final group of cells procured for this test plan.

\section{CONCLUSIONS}

The significant loss of capacity observed in the first group of nickel-hydrogen cells from ATP testing to our initial capacity testing has several possible causes. The activation procedure for these cells followed Rev $F$ of the "Product Specification Nicke1-Hydrogen Battery Cel1" (ref. 6). A hydrogen precharge of $40 \mathrm{psig}$ is completed immediately prior to the conditioning cycles and ATP testing. The hydrogen precharge has recently been deleted from the specification, and nickel-hydrogen manufacturers have suggested that the hydrogen precharge of $40 \mathrm{psig}$ may have caused the noted capacity degradation and resultant double-knee or second plateau discharge. The tweive cells were in a stored, shorted condition for approximately six weeks, and it has been postulated that during this period the hydrogen precharge reacted with and changed the positive plate. At the present time, extensive studies are underway by the vendor to characterize this positive plate change. It was decided that for the second cell build of 24 cells a revised cell activation procedure would be utilized. The 40 psig precharge was reduced to a one atmosphere precharge, or approximately 16 psig.

Hopefully, this change will minimize the capacity loss observed on the first twelve cells. The twenty-four cells recently received will undergo the same receiving, inspection and initial capacity tests as the first twelve to ensure an accurate evaluation of the revised activation procedure. No other parameters in the manufacturing of the cell have been revised. Tests are scheduled for November 1985 on the second build of twenty-four cells.

Cells under LEO cycling have nearly 1000 cycles to date, therefore it is too early yet to draw any conclusions regarding nickel-hydrogen performance. Test control parameters were initially identified as major items for an accurate and reliable test program. Early tests have shown the most reliable method for charge control is ampere-hour integration. The coolant fixtures have been shown to provide excellent thermal conductivity for the removal of heat from the cells. Test control parameters have been optimized, and hopefully cells under the LEO test program will meet the goal of 20,000 cycles. 


\section{REFERENCES}

1. "An Industry and Government Survey: A Nickel-Hydrogen Testing Data Base", Charles Badcock and Martin Milden, The 1984 Goddard Space Flight Center Battery Workshop, p. 583.

2. "Nickel-Hydrogen Spacecraft Module Configurations Study", William B. Collins, Joseph K. McDermott and Owen B. Smith, The 1984 Goddard Space Flight Center Battery Workshop, p. 459.

3. "In-Flight Performance of a Six Ampere-Hour Nickel-Cadmium Battery in Low-Earth-Orbit", Joseph K. McDermott, The 1983 Goddard Space Flight Center Battery Workshop, p. 325.

4. "The Open Circuit Stand Behavior INTELSAT VI Nickel-Hydrogen Batteries and Its Relationship to Charge Rates and Temperature", P. F. Ritterman and A. M. King, Proceedings of the 20th Intersociety Energy Conversion Engineering Conference, P. 1.176.

5. "The GSTAR and SPACENET Nickel-Hydrogen Batteries for Geosynchronous Orbit Applications", Stephen J. Gaston, Proceedings of the 19th Intersociety Energy Conversion Engineering Conference, p. 259.

6. "Product Specification Nickel-Hydrogen Battery Ce11, PS 32014-031 Ref F", Hughes Aircraft Company, 23 June 1980. 
TABLE 1. CELL SUPPLIERS FOR LEO TEST PROGRAM

\begin{tabular}{|c|c|c|c|}
\hline $\begin{array}{c}\text { CELL } \\
\text { SUPPLIER }\end{array}$ & $\begin{array}{l}\text { CELL } \\
\text { TYPE }\end{array}$ & $\begin{array}{l}\text { NUMBER OF } \\
\text { CELLS PROCURED }\end{array}$ & SIATUS \\
\hline EAGLE-PICHER & AIR FORCE & 36 & $\begin{array}{l}12 \text { CELLS RECEIVED } 07 / 85 \\
24 \text { CELLS RECEIVED } 10 / 85\end{array}$ \\
\hline EAGLE-PICHER & COMSAT & 04 & 04 CELLS RECEIVED $08 / 85$ \\
\hline GENERAL ELECTRIC & AIR FORCE & 36 & $\begin{array}{l}20 \text { CELLS SCHEDULED } \\
\text { FOR DELIVERY 01/86 } \\
16 \text { CELLS SCHEDULED } \\
\text { FOR DELIVERY 02/86 }\end{array}$ \\
\hline YARDNEY & MAN-TECH & 06 & 06 CELLS RECEIVED $10 / 85$ \\
\hline
\end{tabular}

TABLE 2. NICKEL-HYDROGEN LEO TEST MATRIX

\begin{tabular}{|c|c|c|}
\hline $\begin{array}{l}\text { DEPTH-OF- } \\
\text { DISCHARGE } \\
\text { TEST }\end{array}$ & $40 \%$ & $60 \%$ \\
\hline $10^{\circ} \mathrm{C}$ & $\begin{array}{l}16 \text { EP CELLS } \\
16 \text { GE CELLS } \\
6 \text { YARDNEY CELLS } \\
4 \text { EP COMSAT CELLS }\end{array}$ & $\begin{array}{l}8 \text { EP CELLS } \\
8 \text { GE CELLS }\end{array}$ \\
\hline $20^{\circ} \mathrm{C}$ & $\begin{array}{l}8 \text { EP CELLS } \\
8 \text { GE CELLS }\end{array}$ & $\begin{array}{l}4 \text { EP CELLS } \\
4 \text { GE CELLS }\end{array}$ \\
\hline
\end{tabular}


TABLE 3. NICKEL-HYDROGEN LEO TEST PARAMETERS

\begin{tabular}{|c|c|c|c|c|}
\hline $\begin{array}{c}\text { TEST } \\
\text { TEMPERATURE }\end{array}$ & DOD & $\begin{array}{c}\text { DISCHARGE } \\
\text { RATE }\end{array}$ & $\begin{array}{c}\text { CHARGE } \\
\text { RATE }\end{array}$ & $\begin{array}{c}\text { RECHARGE } \\
\text { FRACTION }\end{array}$ \\
\hline $10^{\circ} \mathrm{C}$ & $40 \%$ & $34.3 \mathrm{~A}$ & $22.9 \mathrm{~A}$ & 1.05 \\
& $60 \%$ & $51.5 \mathrm{~A}$ & $34.3 \mathrm{~A}$ & 1.05 \\
\hline $20^{\circ} \mathrm{C}$ & $40 \%$ & $34.3 \mathrm{~A}$ & $22.9-24.0 \mathrm{~A}$ & 1.05 To 1.10 \\
& $60 \%$ & $51.5 \mathrm{~A}$ & $34.3-36.0 \mathrm{~A}$ & 1.05 To 1.10 \\
\hline
\end{tabular}

TABLE 4. EAGLE-PICHER ATP CAPACITY VERSUS IN-HOUSE CAPACITY TESTS

\begin{tabular}{|r|c|c|c|}
\hline \multirow{3}{*}{$S / N$} & \multirow{2}{*}{$\begin{array}{c}\text { EAGLE-PICHER } \\
\text { ATP CAPACITY (05/29/85) }\end{array}$} & \multicolumn{2}{|c|}{$\begin{array}{r}\text { MARTIN MARIETTA CAPACITY TEST (07/31/85) } \\
25.0 \text { A D/C TO }\end{array}$} \\
\cline { 3 - 4 } 1 & 34.3 A D/C TO 1.0 VOLT & 1.0 VOLT & 0.5 VOLT \\
\hline 2 & 62.8 A-HR & 46.9 & 55.6 \\
3 & 63.2 A-HR & 46.5 & 57.1 \\
4 & 61.1 A-HR & 48.2 & 57.7 \\
5 & 64.5 A-HR & 47.1 & 57.7 \\
6 & 60.6 A-HR & 46.9 & 55.8 \\
7 & 62.9 A-HR & 45.0 & 55.2 \\
8 & 60.7 A-HR & 47.3 & 57.1 \\
9 & 59.9 A-HR & 46.3 & 56.0 \\
10 & 63.4 A-HR & 48.0 & 57.3 \\
11 & 60.3 A-HR & 46.1 & 57.3 \\
12 & 60.4 A-HR & 46.3 & 57.1 \\
& 59.8 A-HR & 45.9 & 55.2 \\
\hline
\end{tabular}


COLD PLATE TEMPERATURE AND CELL IEMPERATURE LEO CYCLING CONTROL

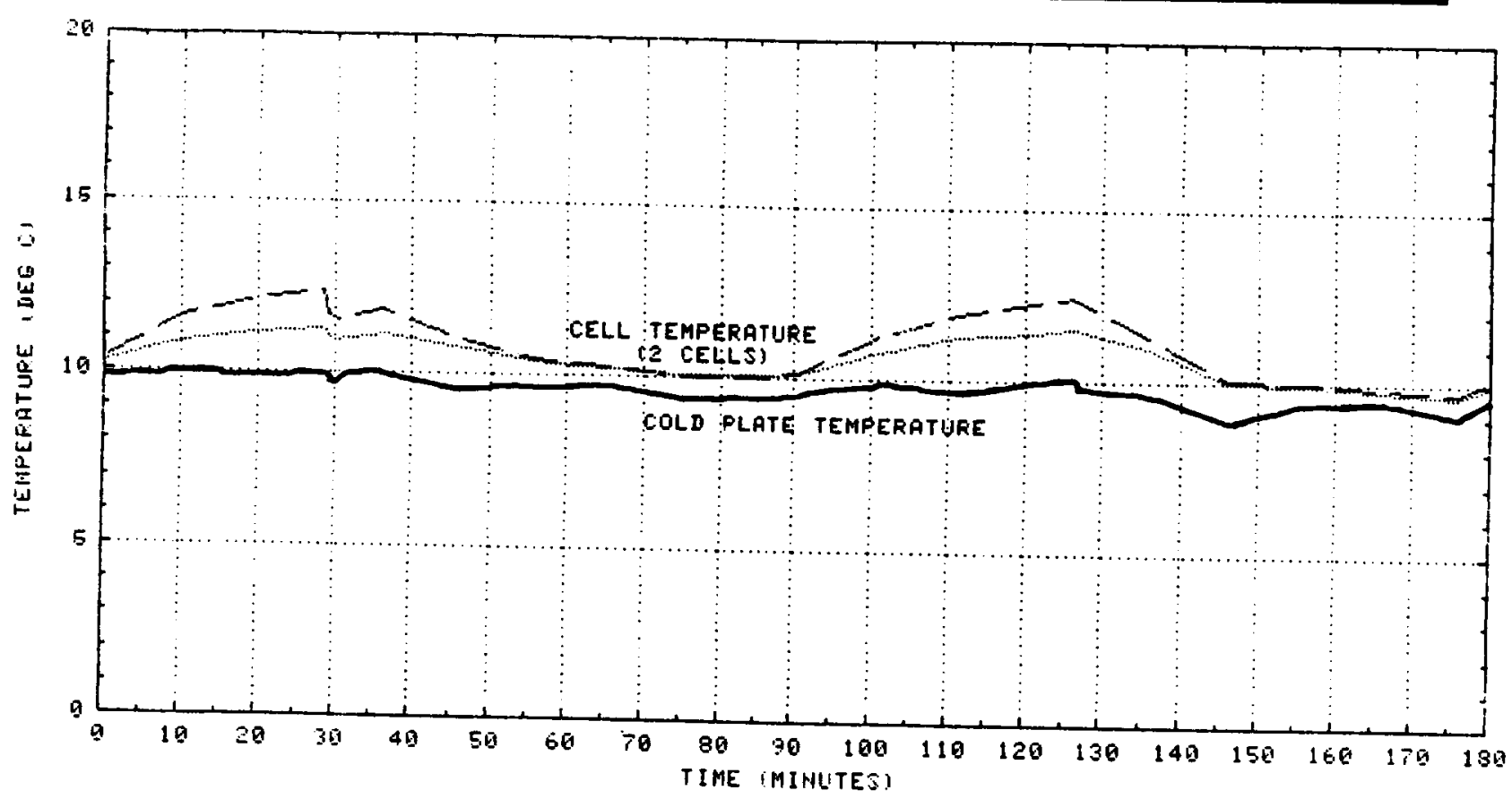

FIGURE 1

INITIAL CELL CAPACITY DISCHARGE CYCLE

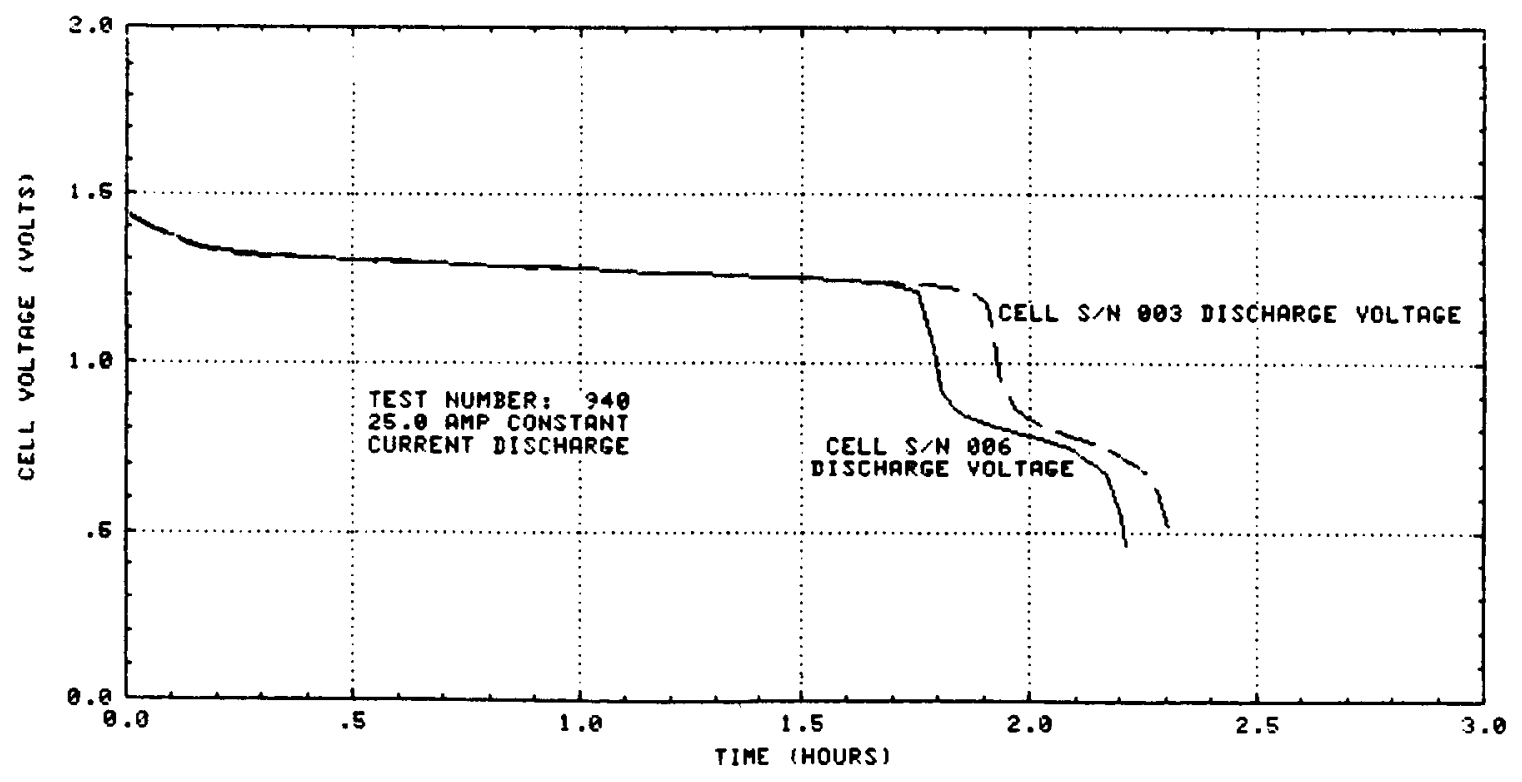

FIGURE 2 


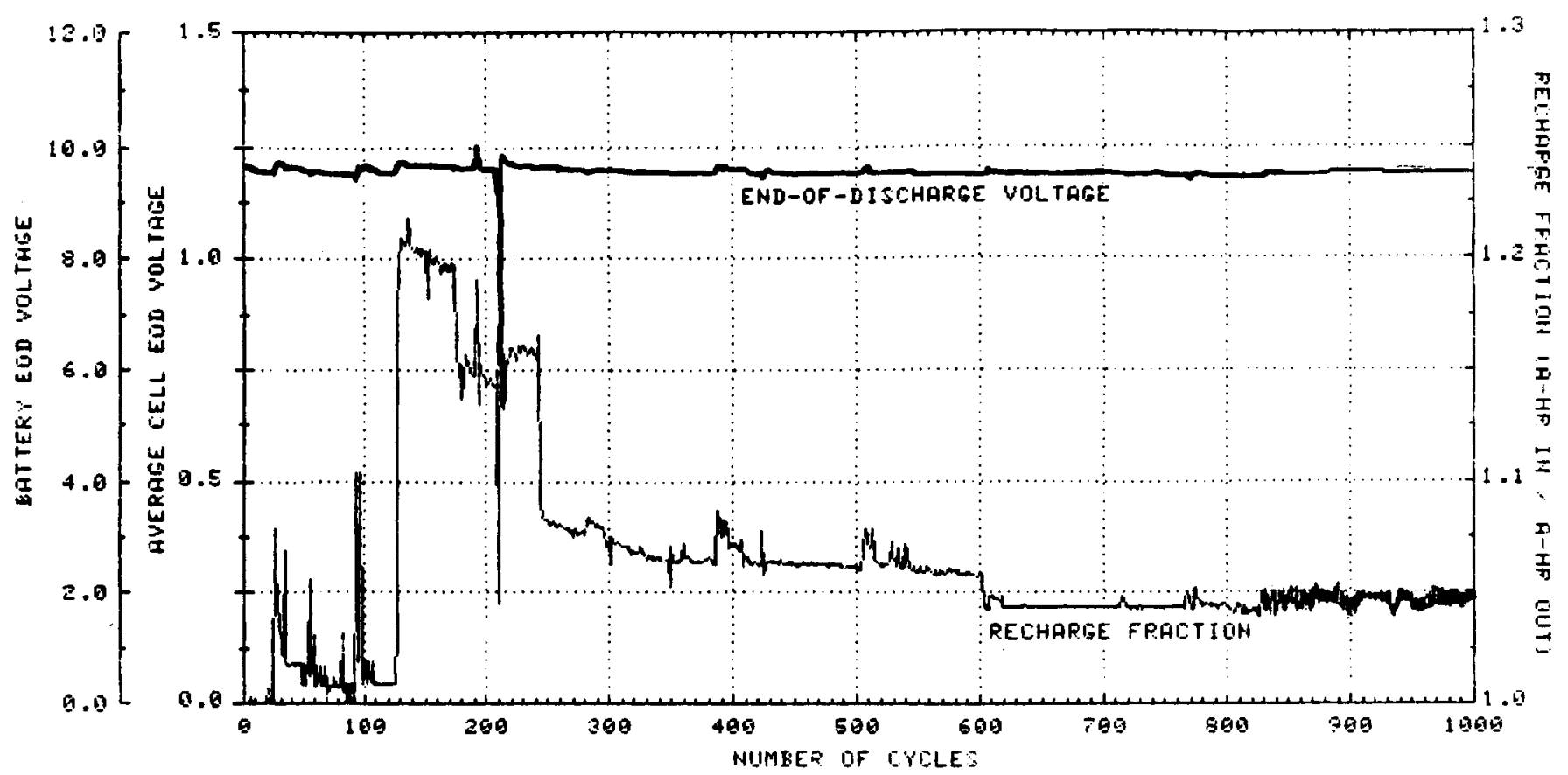

FIGURE 3

\section{EP TEST GROUP ( 4 CELLS) $20^{\circ} \mathrm{C}, 60 \%$ DOD LEO TEST DATA}

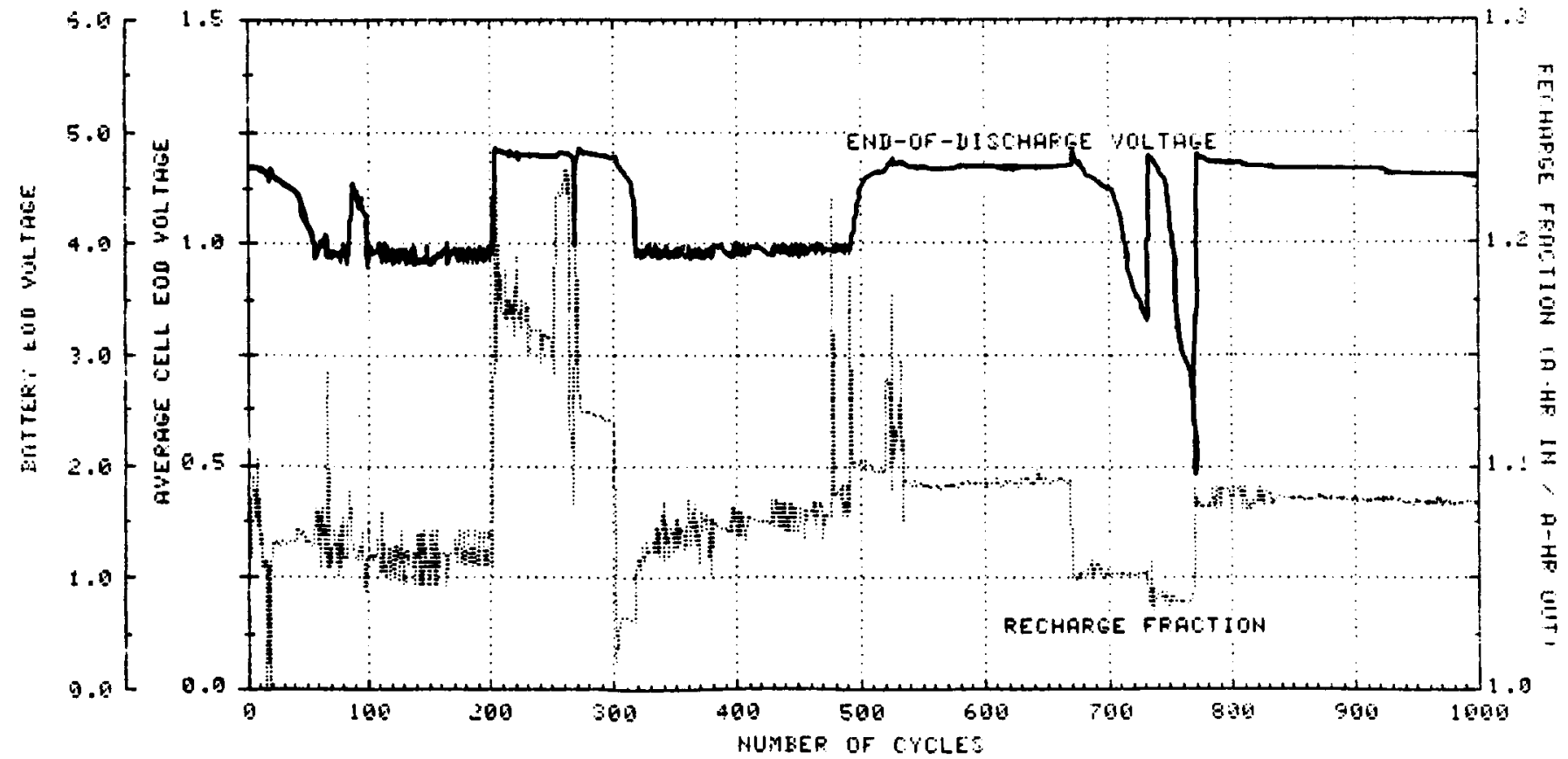

FIGURE 4 
EP COMSAT TEST GROUP ( 4 CELLS) $10^{\circ} \mathrm{C}, 40 \%$ DOD LEO TEST DATA

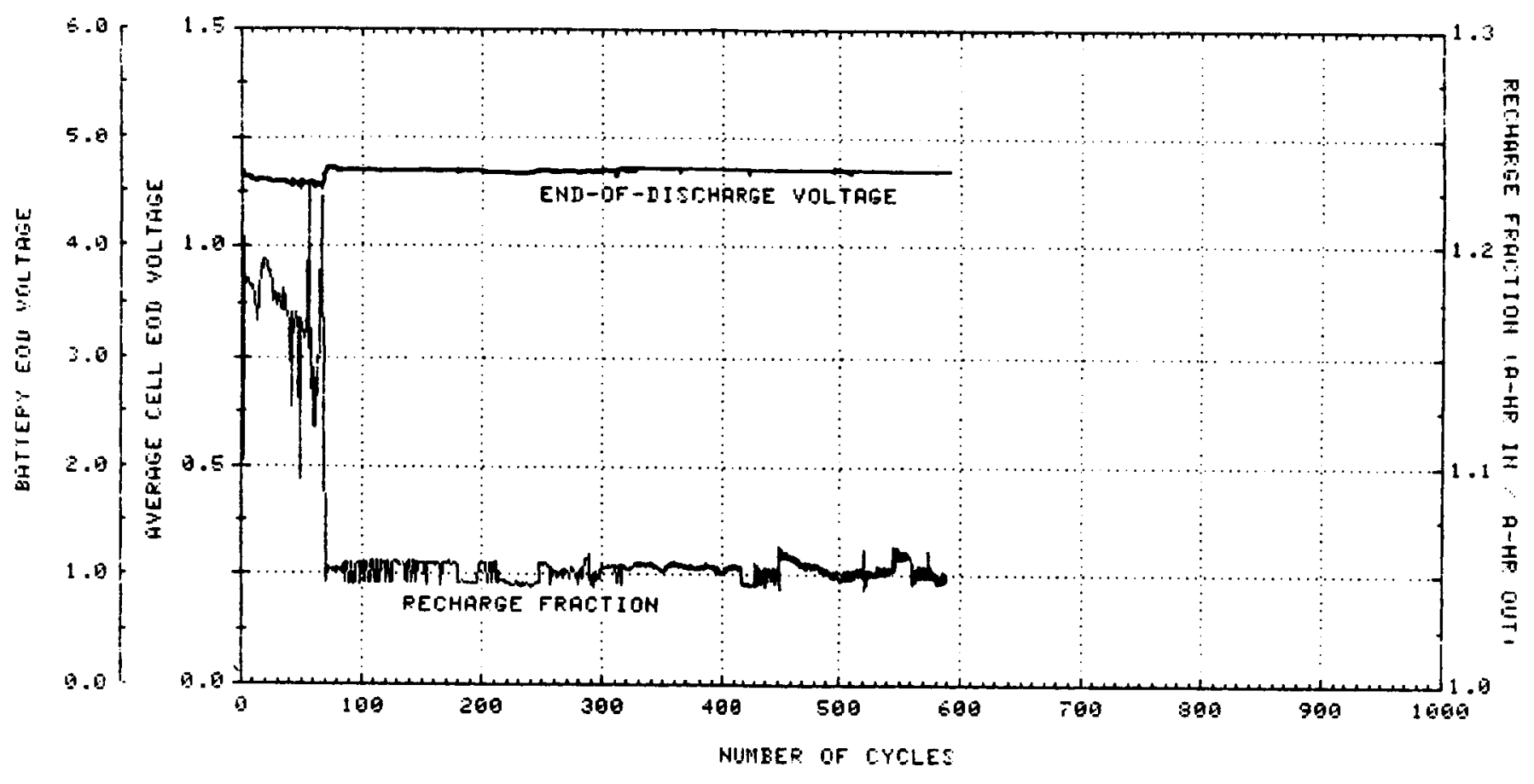

FIGURE 5 